\title{
E-BUSINESS AND ITS APPLICATION IN CONDITIONS OF CENTRAL EUROPEAN MARKET
}

DOI: 10.12776/QIP.V17I1.152

\author{
NACI TOLGA SARUC, PETER DORČÁK, FRANTIŠEK POLLÁK
}

\section{INTRODUCTION}

Talking about e-commerce, we talk about electronic commerce as a whole, thus buying through information and communication technologies (Dorčák and Pollák, 2010). This way of shopping allows customers to purchase products or services without the need for physically travelling (commuting) or being physically present in a brick-and-mortar store (Bačik and Fedorko, 2011). Purchasing a product by phone can, of course, too be considered a purchase without being physically present in a given store (Dahlem, et al., 2010). Ecommerce goes even further, reducing the effort on the so-called "clicking" your mouse button on the "ORDER" icon on the Internet (Frey, 2011).

Several authors Dorčák and Pollák (2010), Kotler et al. (2007), Delina and Vajda (2006), Blažková (2005), Janouch (2010) further argue that the difference between e-business and e-commerce is as follows: e-commerce is part of ebusiness as such, while e-business is a broad portfolio of activities associated with the business. It is basically carrying out business transaction, or realizing any processes related to business or business management with the use of ICT. E-commerce focuses mainly on activities related to trading, namely purchasing, selling or providing support via customer service centres over the Internet (Kaplan and Zrník, 2007).

Selected types of e-business models - B2C: This model of connection within ebusiness is, in general, often a direct connection of companies, firms or organizations with their customers (Spiller \& Baier, 2009). Integration of ICT strategy, quality strategy, and strategy for the business itself is essential within this model. By this, taking advantage of all the benefits that the B2C model offers to organizations can be ultimately be achieved (Suchánek, 2007) . According to Delina and Vajda (2006) the most important benefits include the opportunity to carry out business (depending on whether it is e-business, or directly e-commerce) internationally within the global market, shortening the time required on reactions in the process of provider-customer communication, and, last but not least, a more precise targeting on target customers through a 
more thorough segmentation of customer markets. The world's top players on the B2C market include the Internet giant Amazon.com and its global subsidiaries such as Amazon.co.uk, Amazon.ca etc (Sernovitz, 2009), (Pelsmacker, et al., 2003), (Procházka, 2010). Finally, the B2C market is in recent years also greatly influenced by the American company Apple via its iTunes interface.

The actual e-commerce (sales and purchases) as an integral part of e-business through the B2C model involves strategies and processes, but also actual solutions, allowing mutual organization-customer connection (Kotler and Keller, 2007). This connection offers a wide range of benefits not only for customers in the form of increased comfort, but also for organizations in the form of valuable information, which are suitable for subsequent analysis (Vajda and Delina, 2006), (Frey, 2011), (Chafey, 2009), (Delina and Tkáč, 2010).

The essence of this article is to present selected possibilities of utilising these information.

\section{METHODOLOGY}

The very issue of the possibility of effective use of ICT to support business is extensive. ICT help businesses in different forms. For the purposes of this analysis we set the main objective to point out how it is possible to use the selected e-business applications within the real business environment of SMEs operating in the Central European market. This objective can be decomposed as follows: Based on the information from mutual organization-organization B2B connection (in this case, publisher and distributor) within e-business applications, the objective was then to show benefits of this connection for the organization itself on a specific example.

Characteristics of the research object: The research object is a real company (hereinafter referred to as "organization") from the SMEs environment operating on the Central European market. The research subject is the use of selected ebusiness applications within this organization and within selected specific product.

For the purposes of the analysis the specific product is a monograph entitled Marketing and e-Business (Dorčák and Pollák, 2010). In this case, the selected organization was the publisher of the above monograph.

The main objective will be subjected to statistical testing as follows:

Based on the sales data of the monograph obtained from the EDI interface within publisher-distributor e-business communication, and the data from the analytic interface for websites - Google Analytics - we will attempt to determine the effect of the sales of monograph on traffic of the supporting website, which provides "bonus" content to customers within authorisation zone. The supporting website www.iuniverzita.sk also offered information on the monograph for potential customers. (It should be noted that this analysis is only one of many that 
can be examined within the $\mathrm{B} 2 \mathrm{C}$ connection based on the collected primary information.)

Within this objective the following statistical hypothesis $\mathrm{H} 0$ was set: There is no statistically significant correlation between the sales of the monograph and the total traffic of the supported (promotional) website.

In contrast, the following alternative hypothesis H1 was set: There is a statistically significant correlation between the sales of the monograph and the total traffic of the supported (promotional) website.

Research sample: The research sample consisted of potential as well as real customers of the given organization. Taking the nature of the product into consideration, i.e. monograph dealing with modern marketing in the Internet environment, the basic set - "segment" - can be specified as follows:

- People in productive age

- People using the Internet (Internet visitors, users)

- People with secondary and higher education

- People employed or interested in ICT and marketing in general

- In general, people speaking Slovak

Within the analysis 105 units of the given monograph sold (the number can be interpreted as the number of actual customers) and 330 supporting website (www.iuniverzita.sk) visitors (this figure may be interpreted as a "sample", i.e. the number of actual and potential customers, i.e. users of the supporting website) were dealt with.

Methods of assessment: The main scientific methods within the research were analysis and synthesis. Statistical programs Statistica by Statsoft and Matematica 6.0 were used for the results assessment, while MS Excel, part of the MS Office 2007 Suite, was used for research results processing.

Statistical methods used: Due to the nature of the research as well as the sample size and number of observations, nonparametric tests were chosen as statistical methods. More specifically, Spearman's rank correlation coefficient.

\section{EVALUATION AND DISCUSSION}

Based on the sales data of the monograph obtained from the EDI interface within publisher-distributor e-business communication, and the data from the analytic interface for websites - Google Analytics - we carried out analysis of the effect of the sales of the monograph on traffic of the supporting website, which provided "bonus" content to customers within authorisation zone. The supporting 
website www.iuniverzita.sk also offered information on the monograph for potential customers.

The following two statistical hypotheses were set out in connection with our objective:

Hypothesis H0: There is no statistically significant correlation between the sales of the monograph and the total traffic of the supported (promotional) website.

We also set out an alternative hypothesis $\mathrm{H} 1$ : There is a statistically significant correlation between the sales of the monograph and the total traffic of the supported (promotional) website.

To verify statistical hypotheses a nonparametric test, namely the Spearma'n coefficient was used.

In the first step sequence tables for dependent and independent variables were created.

Table 1 - Sequence table no.1

\begin{tabular}{|c|c|c|c|c|}
\hline Period & $\mathbf{R x}$ & $\mathbf{R y}$ & $d=R x-R y$ & $d^{\wedge} 2$ \\
\hline $01.12 .2010-31.12 .2010$ & 8.0 & 1.0 & 7.00 & 49.00 \\
\hline $01.01 .2011-31.01 .2011$ & 11.0 & 8.0 & 3.00 & 9.00 \\
\hline $01.02 .2011-28.02 .2011$ & 8.0 & 11.0 & -3.00 & 9.00 \\
\hline $01.03 .2011-31.03 .2011$ & 10.0 & 7.0 & 3.00 & 9.00 \\
\hline $01.04 .2011-30.04 .2011$ & 5.0 & 9.5 & -4.50 & 20.25 \\
\hline $01.05 .2011-31.05 .2011$ & 8.0 & 9.5 & -1.50 & 2.25 \\
\hline $01.06 .2011-30.06 .2011$ & 3.5 & 3.5 & 0.00 & 0.00 \\
\hline 01.07. $2011-31.07 .2011$ & 2.0 & 5.0 & -3.00 & 9.00 \\
\hline 01.08. $2011-31.08 .2011$ & 6.0 & 2.0 & 4.00 & 16.00 \\
\hline 01.09. 2011 - 30.09. 2011 & 1.0 & 3.5 & -2.50 & 6.25 \\
\hline $01.10 .2011-31.10 .2011$ & 3.5 & 6.0 & -2.50 & 6.25 \\
\hline
\end{tabular}

Calculation:

$$
r_{s}=\frac{\frac{1}{6}\left(n^{3}-n\right)-\sum_{i=1}^{n} d_{i}^{2}-T_{x}-T_{y}}{\sqrt{\left[\frac{1}{6}\left(n^{3}-n-2 T_{x}\right)\right]\left[\frac{1}{6}\left(n^{3}-n-2 T_{y}\right)\right]}}
$$

$r_{s}=0.197203$

$$
t=r_{s} \sqrt{\frac{(n-2)}{\left(1-r_{s}^{2}\right)}}
$$

$t=0.603458$

$t_{0.995}(n-2)=t_{0.995}(9)=3.25$ 
Since $0.603458<3.25=\mathrm{t}_{0,995}(9)$ we do not reject $\mathrm{H} 0$ at significance level of $\alpha=$ 0.01 , thus we can conclude that there is no statistically significant correlation between the sales of monograph and the total traffic of the supporting (promotional) website.

At the same time, the alternative hypothesis H1 (the significance level of $\alpha=$ 0.01 ) there is a statistically significant correlation between the sales of the monograph and the total traffic of the supported (promotional) website cannot be confirmed. We noted a weak positive correlation on the significance level of $\alpha=$ 0.01 between those variables, but this is not a statistically significant correlation.

Although, based on data from $\mathrm{B} 2 \mathrm{~B}$ and $\mathrm{B} 2 \mathrm{C}$ interface, we failed to confirm the validity of the alternative hypothesis $\mathrm{H} 1$ and that fact, that there is a statistically significant correlation between the sales of monograph and the total traffic of the supporting (promotional) website, we have identified and then showed the real benefits of selected e-business applications, in this case EDI (as a B2B communication channel) and the supporting website (as a B2C communication channel) for this specific case, in terms of acquiring valuable information for subsequent analysis in order to gain a competitive advantage.

\section{CONCLUSION}

It is possible to argue that ability of a company to attract and then retain customers is dependent on the ability to create high quality innovative products and services. Differentiate from the competition is often crucial in terms of the very survival of companies on the market. Nowadays, it is nothing unusual to import almost any product from countries benefiting from significant savings. Efficiency is a significant competitive advantage with regard to local competitors in the battle for customer. Being more effective than a competitor is not only matter of low prices of inputs, but also the matter of responsible management of other non-financial resources, such as time and the pressure on the quality of products and processes. Efficient use of resources based on more effective and transparent communication processes is just one of the benefits of using ebusiness applications and ICT in general. Mutual interactive connection of communicating parties also brings benefits in terms of providing important information needed for effective business, even in real time. Analysis of these information may provide a significant competitive advantage in terms of better understanding of factors affecting business. This can have a positive impact on the effectiveness of SMEs, as such.

\section{REFERENCES}

Bačík, R., Fedorko, R., 2011. Analysis of the avantages of e-shop purchases as compared to shopping in brick and mortar shops with reference to Slovak internet conditions. Organizacja prihodnosti, in Proceedings of 30. mednarodne 
konference o razvoju organizacijskih znanosti, Slovenija, Portorož, 23.25.3.2011, Kranj: Moderna organizacija, 2011, ppS. 30-37.

Blažková, M., 2005. Jak využít internet v marketingu. Grada Publishing, Praha.

Chaffey, D., Chadwik, F. E., Johnston, K., Mayer, R., 2009. Internet marketing. Strategy, Implementation and Practice. $3^{\text {rd }}$ edition. FT Prentice Hall. London.

Dahlen, M., Lange, F., Smith, T., 2010. Marketing Communications: A Brand Narrative Approach. West Sussex, John Wiley \& Sons.

Delina, R., Tkáč, M., 2010. The Impacts of Specific ICT Solutions on Productivity. In: IDIMT-2010: Information Technology - Human Values, Innovation And Economy. Book Editor(s): Doucek, P; Chroust, G; Oskrdal, V. Book Series: Schriftenreihe Informatik. $18^{\text {th }}$ Interdisciplinary Information Management Talks Location: Jindrichuv Hradec, Czech Republic, Sep 08-10, 2010, Vol. 32, pp. 23-32.

Delina, R., Vajda. V., 2006. Teória a prax elektronického obchodovania. 1. vyd. Elfa, Košice (Slovak).

Dorčák. P., Pollák, F. (2010). Marketing and e-Business: Ako sa zorientovat'v pojmoch a procesoch nového marketingu. 1. Vydanie. EZO.sk, s.r.o., Prešov. (Slovak).

Frey, P., 2011. Marketingová komunikace: nové trendy 3.0. 3.vyd. Management Press. Praha. (Czech).

Janouch, V., 2010. Internetový marketing: prosad'te se na webu a sociálních sitích. Computer Press. Brno. (Czech).

Kaplan, M., Zrník, J., 2007. Firemní nákup a e-aukce: jak šetřit čas a peníze. 1. vyd. Grada Publishing. Praha. (Czech).

Kotler, P., Wong, V., Saunders, J., Armstrong, G., 2007. Moderni marketing. 4. evropské vydání. Grada. Praha (Czech).

Kotler, P., Keller, K. L., 2007. Marketing management. 1.vyd. Grada. Praha (Czech).

Pelsmacker, P., Geuens M., Bergh J., 2003. Marketingová komunikace. Grada, Praha. (Czech).

Procházka, D., 2010. První kroky s internetem. Grada. Praha. (Czech).

Sernovitz, A., 2009. Word of Mouth Marketing, Revised Edition: How Smart Companies Get People Talking. Revised edition edition. Kaplan Publishing. New York.

Spiller, L., Baier, M., 2009. Contemporary Direct \& Interactive Market. International ed of 2 nd revised ed edition. Pearson Academic. New Yersey

Suchánek, P., 2007. Internetové obchody a videozáznamy jako prezentace firem. SU OPF. Karviná. (Czech) 


\section{ABOUT THE AUTHOR}

Assoc. Prof. Dr. Naci Tolga Saruc, Sakarya University, Faculty of Economics and Administrative Sciences, Sakarya, Turkey e-mail: ntsaruc@ @akarya.edu.tr.

Assoc. Prof. PhDr. Peter Dročák, PhD., University of Prešov, Faculty of Management, Prešov, Slovakia e-mail: peter@ dorcak.com.

Dr. František Pollák, University of Prešov, Faculty of Management, Prešov, Sovakia, e-mail: frank.pollak@acuityeng.com. 